\title{
Ace Chemistry Classroom Management with LMS Schoology
}

https://doi.org/10.3991/ijim.v14i12.15585

\author{
Mery Napitupulu ( $\left.{ }^{\varpi}\right)$, Daud K Walanda, Detris Poba, \\ Sri H.V. Pulukadang \\ Tadulako University, Palu, Indonesia \\ merytn@gmail.com
}

\begin{abstract}
It is no doubt that information technology has played significant importance in higher education in particular in the era of the 4.0 industrial revolution. The progress in technology is expected to support and facilitate the teaching and learning process. One information technology product that can be used is a learning management system (LMS) such as Schoology. Schoology offers all the tools in classroom management which are needed to create interesting content, support learning activities, and assess student understanding. However, the platform itself being used in a chemistry classroom is still rarely found. For this reason, the purpose of this study is to investigate chemistry classroom management using LMS Schoology. A quantitative-descriptive analysis was used to analyze data. Registered inorganic chemistry undergraduate students $(\mathrm{n}=52)$ of semester IV participated in this study. The data was collected using a 28 -items questionnaire which accumulated the perception of students regarding chemical class management using Schoology. The results of the study showed positive responses toward that management of teaching materials, management discussions, assignments, quizzes/exams, management of communication and ultimately interaction using LMS Schoology aced the chemistry classroom management.
\end{abstract}

Keywords-Lms schoology, classroom management, student perception, chemistry learning

\section{Introduction}

WEB-based learning is now a trend and lifestyle among young learners and old learners. In college, for example, millions of chemistry students conduct experiments online, prepare exams for each chapter by utilizing online resources, listen and watch videos about things. At the same time, professionals also utilize online resources to improve their skills [1]. It is increasingly clear that WEB learning extends to all age groups and all walks of life. Where learners use various technologies to participate in virtual communities to share ideas, comment on projects, and plan, design, implement, develop, or simply discuss practical practices, ideas, or goals together [2]. 
Utilization of technology is continuously developed globally to support student participation, especially in the face of the industrial revolution era 4.0. In this era, teachers and learners integrate technology in teaching and learning. Thus giving an impact on creativity in designing learning that is more effective and interesting [3]. One of the integration of technology in learning is by utilizing a learning management system (LMS) that supports the management and delivery of learning content [4] [5], and as a complement in face-to-face meetings in the classroom to online learning as a whole [6]. In addition, the application of LMS shows that interactions are formed more flexibly through discussion forums, and also teachers and learners can transfer files online without having to face-to-face [7]. These advantages are increasingly complemented by the availability of free LMS, and LMS Schoology is one of them.

LMS Schoology is a platform provided for teachers and learners in the world of education. Where the features possessed allow the instructor to create a real class so as to enable the teacher to provide teaching materials, make announcements, send and return assignments, organize, and evaluate learning and communicate with each other online. Another advantage is that it can be adapted to the needs of individual learners [8]. Learners become more comfortable in communicating with teachers (Pretorius, \& Bijon, 2015). This requires innovation both pedagogically and technology. Innovating thinking significantly and designing an approach to teaching and learning that involves learners [9].

\section{Method}

This study aims to determine students' perceptions of chemistry class management using Schoology. The subjects of the study were 52 fourth semester students who registered the Metal Inorganic Chemistry course whose main material was the chemistry of metal elements including alkali metals, alkaline earth metals, p-block blocks and d-block transition metals and lantanoids and actinoids, in the Educational Study Program Chemistry, Teaching Training and Education Faculty, Tadulako University. For 1 semester students take courses in Inorganic Chemistry using LMS Schoology. Integration of learning tools in the form of reference books (Google ebook), handouts/power points and learning videos (YouTube) for each subject, discussion topics, quizzes and final choice (multiple choice). At the end of the lecture, students fill out a questionnaire about chemistry class management using Schoology. Quantitative descriptive analysis with the help of MS Excel was to analyze data. Collecting data on student perceptions used a validated questionnaire consisting of six (6) criteria which includes 28 question items. Students' perceptions are seen from several aspects including accessibility, flexibility, accuracy in accessing teaching materials, discussion rooms, storage rooms, assignments, making of exam questions as well as additional perceptions about the experience of using Schoology. The results will be measured based on differences in the Mean Score, if $\geq 3.5=$ high, 2.5 - $3.4=$ moderate and $\leq 2.4=$ low $[10]$. 


\section{The Result and Discussion}

\subsection{Accessibility and flexibility System}

This criterion explained the accessibility and flexibility system of LMS Schoology by students in attending the Inorganic Chemistry lectures whose data is summarized in Table 1.

Table 1. System of Accessibility and Flexibility

\begin{tabular}{|c|l|c|c|c|}
\hline No & \multicolumn{1}{|c|}{ Item } & Mean & Deviation Standard & Score \\
\hline 1 & $\begin{array}{l}\text { Can access Schoology via PC, laptop, iPhone, or } \\
\text { Smartphone. }\end{array}$ & 4.48 & .700 & High \\
\hline 2 & $\begin{array}{l}\text { Schoology easily access material information anywhere } \\
\text { and anytime (flexible). }\end{array}$ & 4.04 & .839 & High \\
\hline
\end{tabular}

Table 1 shows students' responses to Schoology's accessibility and flexibility. The analysis shows that Schoology is easily accessed via PCs, laptops, iPhones, and smartphones with a Mean value of 4.48. This value explains the conditions that make it easier for users to be able to access Schoology by using digital tools around their users. Thus, this condition makes it easy to access information about the material anywhere and anytime $(M=4.04)$. Information shared by lecturers can be accessed outside the classroom.

\subsection{Accuracy in accessing teaching material}

The Schoology Platform provides features for Lecturers to be able to add and manage teaching materials. Lecturers can arrange time for students to be able to access teaching materials based on the meeting of each chapter (Table 2).

Table 2. . Appropriate Access to Teaching Material

\begin{tabular}{|c|l|c|c|c|}
\hline No & \multicolumn{1}{|c|}{ Items } & Mean & Deviation Standard & Score \\
\hline 1 & $\begin{array}{l}\text { Can access the handout/power point for each material as } \\
\text { the schedule of each chapter. }\end{array}$ & 4.12 & .704 & High \\
\hline 2 & $\begin{array}{l}\text { Can access video on time after the lecturer upload it } \\
\text { through Schoology }\end{array}$ & 3.75 & .860 & High \\
\hline 3 & $\begin{array}{l}\text { Can access online textbooks of each chapter based on the } \\
\text { time specified by the lecturer. }\end{array}$ & 3.98 & .804 & High \\
\hline 4 & $\begin{array}{l}\text { Can access teaching materials through Schoology, but not } \\
\text { according to the time determined by the lecturer/not based } \\
\text { on the schedule of each chapter. }\end{array}$ & 3.15 & 1.195 & $\begin{array}{l}\text { Mode } \\
\text { rate }\end{array}$ \\
\hline
\end{tabular}

Teaching materials consist of handouts/power points, learning videos, online textbooks, and other teaching materials were initially uploaded to the Schoology platform through add materials by regulating student access times. The material is placed in each of the I - VIII meeting folders based on a mutually agreed meeting. The folder would direct and streamline the course of learning with Schoology augmentation. 
Then access the second meeting folder, and so on until the VIII meeting. Students timely visit each meeting folder in which there is a handout $(\mathrm{M}=4.12)$, as well as video or textbook online ( $\mathrm{M}=3.75$ and $\mathrm{M}=3.98)$. This is useful in order to be able to access material that is added by the lecturer and used as a source of learning before face to face in the classroom. Students are given time to think independently before learning in the classroom. Through setting the due date in accessing material, students will be more motivated to read, watch, and then conduct analysis related to problem solving. Introduction by using video can increase student satisfaction that demands an interactive learning experience [11]. In addition, students are required to work more professionally [12].

\subsection{Discussion room}

Discussion room is a place for students to be able to communicate. Schoology is an LMS that prepares features for the discussion room in the add materials section. With this feature, students are trained to have the ability to interact and communicate with lecturers or between students through the discussion wall without having to meet in person [13].

Table 3. Discussion Room

\begin{tabular}{|c|l|c|c|c|}
\hline No & \multicolumn{1}{|c|}{ Item } & Mean & Deviation Standard & Score \\
\hline 1 & $\begin{array}{l}\text { Actively involved in discussions for the material in a } \\
\text { chapter that has a discussion topic. }\end{array}$ & 3.88 & .943 & High \\
\hline 2 & $\begin{array}{l}\text { Not actively involved in discussions for material in } \\
\text { chapters that have discussion topics. }\end{array}$ & 2.29 & 1.319 & Moderate \\
\hline 3 & $\begin{array}{l}\text { The ideas put forth in the discussion forum through } \\
\text { Schoology come from their own thoughts. }\end{array}$ & 3.33 & .901 & Moderate \\
\hline 4 & $\begin{array}{l}\text { The ideas put forth in discussion forums through } \\
\text { Schoology are sourced from the internet. }\end{array}$ & 3.17 & 1.004 & Moderate \\
\hline
\end{tabular}

This study also looked at student involvement as well as ideas conveyed through chemistry learning that were coordinated with Schoology. Item 1 shows the value of $\mathrm{M}=3.88$ with a high score. That is, students agree that using Schoology that is segmented in chemistry learning, students become actively involved in discussions for any material that has a discussion topic. The ideas conveyed can come from their own thoughts $(M=3.33)$ or sourced from the internet $(M=3.17)$. From this study, it can be seen that the online discussion formed providing an understanding of Schoology as e-learning can be identified as a new learning experience for college students [14].

\subsection{Storage space}

Storage space is an inseparable part of chemistry class management using Schoology. By applying Schoology in chemistry learning, at the same time lecturers and the students create storage space. The storage space in question is Google's Google Drive which is integrated with gmail. By registering a gmail account with Schoology, it would automatically connect to Google Drive. Likewise, in Schoology there is 
Google Drive Organization which allows lecturers to add Google docs or draw directly without leaving the Schoology platform. When the lecturer distributes google docs containing learning material, the lecturer automatically makes a copy for all students.

Table 4. Storage Space

\begin{tabular}{|c|l|c|c|c|}
\hline No & \multicolumn{1}{|c|}{ Item } & Mean & Deviation Standard & Score \\
\hline 1 & $\begin{array}{l}\text { The Google Drive Assignments App on Schoology } \\
\text { makes it easy to access copies of assignments from } \\
\text { lecturers that are automatically stored in Google } \\
\text { Drive. }\end{array}$ & 3.98 & .896 & High \\
\hline 2 & $\begin{array}{l}\text { Google Drive App makes it easy to be able to edit } \\
\text { files provided by lecturers then share them back to } \\
\text { lecturers through Schoology and without logging out } \\
\text { of Schoology. }\end{array}$ & 3,65 & High \\
\hline 3 & $\begin{array}{l}\text { Can create and set folders in the Google Drive App } \\
\text { to make it easier to store files or copies. }\end{array}$ & 3,65 & .968 & High \\
\hline 4 & $\begin{array}{l}\text { The Google Drive App on Schoology does not have } \\
\text { a limit on file storage as long as it has enough stor- } \\
\text { age. }\end{array}$ & 3,98 & .837 & High \\
\hline
\end{tabular}

Items 1 and 2 in Table 4 show mean values of 3.98 and 3.65 which identify high scores. The score explains that the Google Drive Assessment App integrated in Schoology makes it easy for students to get a copy of an assignment from a lecturer without having to download it first. In addition, students can directly make edits without leaving the Schoology platform and then sending it back to the lecturer. The added tasks will be automatically saved in the Google Drive Assigsment folder. Thus, this condition makes it easier for lecturers to check the collection of student assignments. There is no limit to electronic file storage, as long as Drive capacity is sufficient $(\mathrm{M}=3.98)$.

\subsection{Assignment}

To collect assignments, students are always asked to meet directly with lecturers or collect these assignments to the fellow students first. Applying Schoology in chemistry learning, does not require face to face in collecting assignments.

Table 5. Assignment Submission

\begin{tabular}{|c|l|c|c|c|}
\hline No & \multicolumn{1}{|c|}{ Item } & Mean & Deviation Standard & Score \\
\hline 1 & $\begin{array}{l}\text { Submit assignments anytime and anywhere without } \\
\text { having to meet with the lecturer or entrusted to } \\
\text { classmates. }\end{array}$ & 4.71 & .572 & High \\
\hline 2 & $\begin{array}{l}\text { Assignment submission does not require hardcopy } \\
\text { (in paper form) but only by submitting soft files. }\end{array}$ & 4.79 & .498 & High \\
\hline 3 & $\begin{array}{l}\text { Submit assignments on time through notification of } \\
\text { due date. }\end{array}$ & 4.71 & .572 & High \\
\hline
\end{tabular}

Another benefit of learning chemistry using Schoology is that gathering tasks can be done remotely. The results of the study on student perceptions about the submis- 
sion of the assignments, that in submitting the assignments can be done anywhere and anytime $(M=4.71)$. Students do not have to come to see the lecturer at a certain time while carrying out assignments in paper form. Students who are at a friend's house, hanging out, or doing activities outside the home and campus can send assignments. Where, the submitted assignment does not require hardcopy (in paper form) $(\mathrm{M}=$ 4.79). All you need to do is submit the soft file stored on your laptop or smartphone while traveling. This allows students to submit assignments on time before the assignment due date $(M=4.71)$.

\subsection{Making test items}

Making exam questions also raises the advantage of using Schoology in chemistry learning. As usual, when the exam arrives the lecturer must type the questions in word then print them and copy as many students.

Table 6. Making Test Items

\begin{tabular}{|l|l|c|c|c|}
\hline No & \multicolumn{1}{|c|}{ Item } & Mean & Deviation Standard & Score \\
\hline 1 & $\begin{array}{l}\text { It is easy to use to create problems in which there are } \\
\text { chemical formulas, chemical reactions, other chemical } \\
\text { symbols, superscripts, and subscripts. }\end{array}$ & 3.63 & .929 & High \\
\hline 2 & $\begin{array}{l}\text { It is easy to use to answer the essay quiz correctly because } \\
\text { it can be limited by the number of letters. }\end{array}$ & 3.48 & .980 & Moderate \\
\hline 3 & $\begin{array}{l}\text { Schoology makes it easy for me to answer the same quiz } \\
\text { repeatedly over and over to get the truth to the specified } \\
\text { amount. }\end{array}$ & 3.65 & .861 & High \\
\hline 4 & $\begin{array}{l}\text { Easy to use to see the quis score that appears after } \\
\text { repetition. }\end{array}$ & 4.58 & .667 & High \\
\hline
\end{tabular}

The above does not apply when Schoology is applied. Schoology's features in the form of create test / quiz make it easier for lecturers to be able to make chemical problems related to chemical formulas, reactions, chemical symbols, superscripts and subscripts. Students see that Schoology supports if it is applied in making chemical problems $(M=3.63)$. The essay question given can be regulated by the number of letters, so students can give the right and correct answers $(M=3.48)$. Then repeating the same questions over and over, it can also be done by the create test / quiz feature if students want to get the answers they think are the most appropriate $(M=3.65)$. Where the highest score that appears when repetition, so repeating answers repeatedly is not in vain $(\mathrm{M}=4.58)$.

\section{Conclusion}

The integration of learning tools in LMS Schoology shows that the system of accessibility and flexibility, the accuracy of accessing teaching materials, the presence of discussion rooms, storage space, task collection, and making of exam questions improve classroom management especially in inorganic chemistry lectures. Overall, 
by adding Schoology as one of the LMS in learning, it provides benefits and ease in managing the learning process.

\section{$5 \quad$ References}

[1] Bonk, J. C. (2009). The world is open: How web technology is revolutionizing education.

[2] Davidson, C. N., \& Goldberg, D. T. (2009). The Future of Learning Institutions in a Digital Age.

[3] Hussin, A. (2018). Education 4.0 Made Simple: Ideas For Teaching. International Journal of Education and Literacy Studies, 6(3), 92.

[4] Lonn, S., \& Teasley, S. D. (2009). Saving time or innovating practice: Investigating perceptions and uses of Learning Management Systems. Computers and Education, 53(3), 686-694. https://doi.org/10.1016/j.compedu.2009.04.008

[5] Neto, F. M. M. \& Brasileiro, F. (2006). Advances in Learning. Information Resources Press Arlington.

[6] Ladyshewsky, R. K. (2013). Instructor Presence in Online Courses and Student Satisfaction. International Journal for the Scholarship of Teaching and Learning, 7(1). https://doi.org/10.20429/ijsotl.2013.070113

[7] Pierre, S. (2007). E-learning networked environments and architectures: a knowledge processing perspective.

[8] Sanchez Garcia, L. F., Sebastiá-Amat, S., Molina Garcia, N., \& Saiz Colomina, S. (2018). Schoology As an Alternative To Traditional Teaching Tools for University Students. EDULEARN18 Proceedings, 1(September 2019), 7514-7520 https://doi.org/10.21125 /edulearn.2018.1754

[9] Garrison, D. R. (2011). E-Learning in the 21st century: A framework for research and practice, Second edition.

[10] Field, Andy. (2009). Discovering Statistic Using SPSS : Third Edition

[11] Olsadhan, O. A, Alhomod, S., \& Shafi, M. M. (2014). Multimedia based e-learning: design and integration of multimedia content in e-learning. International Journal of Advanced Corporate Learning, 9(3), 26 - 30. https://doi.org/10.3991/ijet.v9i3.3308

[12] Ng, Z. H. \& Baharom, S. S. (2018). An analysis on adult learner's satisfaction ini online education programmes. International Journal of Interactive Mobile Technologies, 12(7), 71 - 85. https://doi.org/10.3991/ijim.v12i7.9665

[13] Cavus, N. (2015). Distance Learning and Learning Management Systems. Procedia Social and Behavioral Sciences, 191(June), 872-877. https://doi.org/10.1016 j.sbspro.2015.04.611

[14] Ellis, R. A., Ginns, P., \& Piggott, L. (2009). E-learning in higher education: some key aspects and their relationship to approaches to study. Higher Education Research and Development, 28(3), 303-318. https://doi.org/10.1080/07294360902839909

\section{Authors}

Mery Napitupulu, Daud K Walanda, Detris Poba and Sri H.V. Pulukadang work in the Department of Mathematic and Science Education for Tadulako University, Palu Indonesia.

Article submitted 2020-03-27. Resubmitted 2020-05-14. Final acceptance 2020-05-17. Final version published as submitted by the authors. 